\title{
Evaluation of Protein Levels in Diets for Salema Porgy (Sarpa salpa) Juveniles, a New Candidate Species for the Mediterranean Aquaculture
}

\author{
Merve Sahinyilmaz ${ }^{1}$, Murat Yigit ${ }^{2, *}$ \\ ${ }^{1}$ Graduate School of Natural and Applied Sciences, Department of Aquaculture, Canakkale Onsekiz Mart University, Canakkale, Turkey \\ ${ }^{2}$ Faculty of Marine Sciences and Technology, Department of Marine Technology, Canakkale Onsekiz Mart University, Canakkale, Turkey
}

\section{Email address:}

mrv.shnylmz@gmail.com (M. Sahinyilmaz), muratyigit@comu.edu.tr (M. Yigit)

${ }^{*}$ Corresponding author

\section{To cite this article:}

Merve Sahinyilmaz, Murat Yigit. Evaluation of Protein Levels in Diets for Salema Porgy (Sarpa salpa) Juveniles, a New Candidate Species for the Mediterranean Aquaculture. Journal of Food and Nutrition Sciences. Vol. 5, No. 3, 2017, pp. 107-115. doi: $10.11648 /$ j.jfns.20170503.17

Received: April 9, 2017; Accepted: April 20, 2017; Published: May 9, 2017

\begin{abstract}
In the present study, the effects of different dietary protein levels on salema porgy, Sarpa salpa (Linnaeus, 1758) juveniles were investigated. Six iso-caloric (20 kJ/g diet) diets with increasing protein levels $(30,37,40,47,50$, and $57 \%$ ) were formulated. Each test diet was randomly fed to triplicate groups of 13 juvenile fish (initial mean weight $19.28 \pm 0.13 \mathrm{~g}$ ) to satiety over 90 days. Growth performance and feed utilization were best with low dietary protein levels of 30 and $37 \%$, but decreased with diets containing protein levels over $40 \%$. Ammonia nitrogen excretion showed an increasing trend as dietary protein levels gradually increased, whereas retention rates of ammonia nitrogen per intake were highest in the low protein groups of 30 or $37 \%$. The analyses of specific growth rate by broken-line regression indicated that the optimal dietary level of protein for salema porgy juvenile were $33.6 \%$ under the conditions applied in this study. As a result, S. salpa demonstrated better growth with low protein diets, showing that this marine fish could be a promising candidate for a sustainable and environment friendly aquaculture industry.
\end{abstract}

Keywords: Salema Sarpa salpa, Protein Requirement, Growth Performance, Feed Efficiency, Nitrogen Retention

\section{Introduction}

The growing trend of marine aquaculture in southern European seas has doubled its production in the last ten years and reached about 276.000 tons with a total income of 1.783.000.000 US dollars in year 2014 [1]. It is estimated that the world population might reach 8.5 billion in year 2030 [2], where the need for human food will increase drastically. The aquaculture industry, with its increasing trend seems to be capable to supply an important amount of the food demand for human consumption. Nevertheless, seabream and seabass are the two main fish species in the Mediterranean with a production around 200.000 tons in Greece and Turkey [1], and the sales value of these two species are in pressure due to the high production rate and limited product diversity in the market. The introduction of new fish species in the market may trigger the demand and expand product diversity with new market opportunities. Salema porgy $(S$. salpa) is a member of the Sparidae family, known as a herbivorous fish species, feeding on plants, distributed around seagrass such as Posedonia sp. or Cymodocea sp. near the shore on sandy, or rocky sea bottom $[3,4]$. Salema porgy can be found in a wide range of area from shallow waters to $70 \mathrm{~m}$ deep water layers in the eastern part of the Atlantic (from the North Sea to Cape of Good Hope, the Canaries and Cape Verde Islands, in the Mediterranean and the Black sea), and in the western part of the Indian Ocean (from Mozambique to Cape of Good Hope) $[5,6])$. Schooling behaviour of salema porgy around cage farms in the Mediterranean has been reported in an earlier study [7], feeding on uneaten pellets that disperse from the fish pens, which is an indication that salema porgy can easily adapt to artificial pellet diets. From this point of view, salema porgy might be potential marine fish species for the Mediterranean aquaculture industry. 
In contrast to gilthead seabream, or other sparid fishes, lower dietary protein requirements of salema porgy could be expected due to its herbivorous nature. Considering the rapid expansion of the world aquaculture industry and the disorganized or irregular state of the global capture fisheries which supplies the ingredients for aqua-diets, the demand for fishmeal and fish oil is likely to increase significantly. During the $2010-2030$ period prices are expected to increase by $90 \%$ for fishmeal and $70 \%$ for fish oil according to [8]. For a sustainable development of the aquaculture industry, a gradual decline of capture fisheries as protein supply for fish feed production has been reported as essential [9]. Based on the increase of global fishmeal costs, an expected decrease of fish meal usage in aqua-diets in the long term has been reported by [10]. Due, nowadays researchers have intensified their studies on the replacement of fishmeal or fish oil by less expensive alternative sources [11]. Besides, Msangi et al. [8] suggested that in the face of higher fishmeal and fish oil prices, the substitution of fish species with less fishmeal requirements should also be considered and preferred for the marine aquaculture industry. Salema porgy ( $S$. salpa) is a sparid fish, frequently seen around aquaculture cage farms in the Mediterranean and the Aegean Seas. Neofitou [12] reported that, salema together with striped mullet (Mugil sephalus) and white trevally (Pseudocaranx dentex) captured around fish cages in the Mediterranean had a stomach with pellets in great quantities. Furthermore, schooling behaviour and feeding on uneaten pellets around floating cage farms for salema in the Mediterranean has also been reported by [7]. These observations strengthens the potential of salema porgy as a candidate marine fish species for the Mediterranean aquaculture industry.

Several reports on the ecology, reproductive biology, agegrowth variation or geographic distribution of the wild populations of salema porgy [3, 13-16] are available, however, information on their nutritional requirements relative to their feeding habits is still lacking and needs to be provided. Hence, this is the first attempt to assess the protein requirements and fed utilization of salema porgy with reference to growth performance, fish body bio-chemical composition and nitrogen budget under controlled culture conditions.

\section{Materials and Methods}

\subsection{Experimental Fish and Rearing Conditions}

The feeding trial was conducted in a marine recirculating aquaculture system. Initial and final fish were weighed individually (precision $0.01 \mathrm{~g}$ ). At intervals of 30 and 60 days during the course of the feeding trial however, fish were mass weighed in buckets filled with seawater in order to avoid handling and netting stress. Before weighing, fish were deprived of feed for one day. Experimental fish with initial mean weight of $19.28 \pm 0.13 \mathrm{~g}$ were placed into 18 circular polyethylene tanks with a water volume of $200 \mathrm{~L}$. A factorial design of $6 \times 3$ was applied and a total of 234 fish were randomly stocked in six groups of tanks with 13 fish per tank, and 3 replicates per treatment. Experimental fish were adapted for a period of 1 month to the culture conditions prior to start of feeding trial, which was initiated when all fish accepted pellets. Seawater was supplied to the tanks at a flow rate of $28 \mathrm{~L} / \mathrm{min}$. Aeration was continuously supplied by air-stones and the photoperiod regime was a natural light course $\left(40^{\circ} 04^{\prime} 37.47^{\prime \prime} \mathrm{N}-26^{\circ} 21^{\prime} 39.04^{\prime \prime} \mathrm{E}\right)$. Throughout the feeding trial, ambient water parameters such as temperature, salinity, dissolved oxygen, $\mathrm{pH}$ were measured periodically using a YSI multi-probe water analyser. Total ammonia nitrogen $\left(\mathrm{NH}_{3}-\mathrm{N}\right)$ was determined by the Nessler method using a portable spectrophotometer.

\subsection{Experimental Diets and Feeding}

Practical diets were formulated and produced with commercially available ingredients. All the test diets were formulated to be iso-caloric on a gross energy $(20.0 \mathrm{~kJ} / \mathrm{g}$ diet $)$ basis and to contain increasing levels of protein $(30,37,40$, 47, 50 and 57\%). Total n-3 highly unsaturated fatty acid (HUFA) contents averaged $3.6 \mathrm{~g} / \mathrm{kg}$ for all test diets. Brown fish meal (anchovy, Blacksea origin) was used as a sole protein source. Ingredients and chemical composition of test diets are given in Table 1, and the amino acid profiles of the experimental diets are presented in Table 2.

Table 1. Ingredients and proximate composition of the experimental diets.

\begin{tabular}{|c|c|c|c|c|c|c|}
\hline \multicolumn{7}{|c|}{ Experimental diet / Protein level } \\
\hline Ingredient (g/kg DM) & D1/30 & D2/37 & D3/40 & D4/47 & D5/50 & D6/57 \\
\hline Fish meal $^{1}$ & 410 & 490 & 565 & 647 & 730 & 810 \\
\hline Corn starch & 50 & 50 & 50 & 50 & 50 & 50 \\
\hline Dextrin & 405 & 335 & 265 & 190 & 115 & 43 \\
\hline Fish oil (FO) & 90 & 80 & 75 & 68 & 60 & 52 \\
\hline Vit-min $\operatorname{mix}^{2}$ & 40 & 40 & 40 & 40 & 40 & 40 \\
\hline Cholin chloride & 5 & 5 & 5 & 5 & 5 & 5 \\
\hline Total & 1000 & 1000 & 1000 & 1000 & 1000 & 1000 \\
\hline \multicolumn{7}{|c|}{ Proximate composition ( $\%$ dry matter, except for moisture) } \\
\hline Moisture & 8.40 & 9.00 & 8.74 & 8.91 & 8.41 & 8.51 \\
\hline Crude protein & 29.4 & 36.7 & 41.4 & 46.2 & 52.1 & 57.2 \\
\hline Crude lipid & 16.0 & 17.9 & 17.1 & 18.3 & 18.4 & 19.7 \\
\hline Crude ash & 4.46 & 5.07 & 6.67 & 7.53 & 8.64 & 9.14 \\
\hline $\mathrm{NFE}^{3}$ & 41.8 & 31.3 & 26.1 & 19.0 & 12.5 & 5.41 \\
\hline $\mathrm{GE}(\mathrm{kJ} / \mathrm{g} \text { diet })^{4}$ & 20.1 & 20.7 & 20.6 & 21.0 & 21.3 & 21.8 \\
\hline GE (kcal/g diet) & 4.80 & 4.96 & 4.93 & 5.02 & 5.08 & 5.20 \\
\hline $\mathrm{P}: \mathrm{E}(\mathrm{mg} / \mathrm{kJ})^{5}$ & 14.6 & 17.7 & 20.1 & 22.0 & 24.5 & 26.3 \\
\hline $\mathrm{PE} / \mathrm{TE}$ & 0.35 & 0.42 & 0.47 & 0.52 & 0.58 & 0.62 \\
\hline Crude lipid in FM (\%) & 8.50 & 8.50 & 8.50 & 8.50 & 8.50 & 8.50 \\
\hline Lipid from FM (\%) & 3.49 & 4.17 & 4.80 & 5.50 & 6.21 & 6.89 \\
\hline$\Sigma$ FO in diet $(\%)$ & 12.5 & 12.2 & 12.3 & 12.3 & 12.2 & 12.1 \\
\hline n-3 HUFA in FO $(\%)^{\mathrm{a}}$ & 29.8 & 29.8 & 29.8 & 29.8 & 29.8 & 29.8 \\
\hline$\sum \mathrm{n}-3$ HUFA in $\operatorname{diet}(\%)$ & 3.72 & 3.62 & 3.66 & 3.66 & 3.63 & 3.60 \\
\hline
\end{tabular}

${ }^{1}$ Anchovy meal, Blacksea-Turkey

${ }^{2}$ Vitamin mixture (per $1 \mathrm{mg}$ ): Vit.A $65.000 \mathrm{IU}$, Vit.D3 $45.000 \mathrm{IU}$, Vit.E 25 IU; Vit.K3 $5 \mathrm{mg}$, Vit.B1 $12.5 \mathrm{mg}$, Vit.B2 $12.5 \mathrm{mg}$, Vit.B6 $15 \mathrm{mg}$, Vit.B12 $0.025 \mathrm{mg}$ and ascorbic acid $120 \mathrm{mg}$; Mineral mixture (per $1 \mathrm{mg}$ ): Ca 100 $\mathrm{mg}$, P $50 \mathrm{mg}$, K $30 \mathrm{mg}$, Na 20 mg, Mg $10 \mathrm{mg}$, Fe $22 \mathrm{mg}$, Zn $3 \mathrm{mg}$, Mn $3 \mathrm{mg}$, $\mathrm{Cu} 1.8 \mathrm{mg}$, Co $0.15 \mathrm{mg}$, I $0.12 \mathrm{mg}$, Se $0.05 \mathrm{mg}$, DL-calcium pantothenate 40 $\mathrm{mg}$, niacin $50 \mathrm{mg}$, folic acid $2.5 \mathrm{mg}$, biotin $0.08 \mathrm{mg}$ and inositol $75 \mathrm{mg}$.

${ }^{3}$ Nitrogen free extract $=100-($ crude oil + crude ash + crude protein $)$

${ }^{4}$ Gross energy; calculated based on energy fuels of $23.6 \mathrm{~kJ} / \mathrm{g}$ protein, 39.5 $\mathrm{kJ} / \mathrm{g}$ lipid and $17.2 \mathrm{~kJ} / \mathrm{g}$ NFE.

${ }^{5}$ Protein-enerji ratio $=\mathrm{mg}$ protein $/ \mathrm{kJ}$ energy

${ }^{6} \mathrm{PE} / \mathrm{TE}=$ energy from protein $/$ total energy

$\Sigma \mathrm{n}-3$ HUFA in diet $(\mathrm{g} / \mathrm{kg})=(\Sigma$ fish oil in diet, $\mathrm{g} / \mathrm{kg}) \times(\% \mathrm{n}-3$ HUFA in fish oil used) 
Table 2. Amino acid profiles of test diets with increasing levels of protein $(g / 16 g N)$.

\begin{tabular}{llllllll}
\hline Amino acid & \multicolumn{7}{l}{ Experimental diet / Protein level } \\
\hline (\%/dry matter) & $\begin{array}{l}\text { Fish } \\
\text { meal }^{\mathbf{a}}\end{array}$ & $\mathbf{3 0}$ & $\mathbf{3 7}$ & $\mathbf{4 0}$ & $\mathbf{4 7}$ & $\mathbf{5 0}$ & $\mathbf{5 7}$ \\
\hline Arginine & 4.11 & 1.69 & 2.01 & 2.32 & 2.66 & 3.00 & 3.33 \\
Lysine & 5.49 & 2.25 & 2.69 & 3.10 & 3.55 & 4.01 & 4.45 \\
Histidine & 1.76 & 0.72 & 0.86 & 0.99 & 1.14 & 1.28 & 1.43 \\
Isoleucine & 3.38 & 1.39 & 1.66 & 1.91 & 2.19 & 2.47 & 2.74 \\
Leucine & 5.43 & 2.23 & 2.66 & 3.07 & 3.51 & 3.96 & 4.40 \\
Valine & 3.81 & 1.56 & 1.87 & 2.15 & 2.47 & 2.78 & 3.09 \\
Methionine & 2.16 & 1.16 & 1.38 & 1.59 & 1.82 & 2.06 & 2.28 \\
Phenylalanine+Tyrocine & 5.47 & 2.24 & 2.68 & 3.09 & 3.54 & 3.99 & 4.43 \\
Threonine & 3.00 & 1.23 & 1.47 & 1.70 & 1.94 & 2.19 & 2.43 \\
Triptophan & 0.82 & 0.34 & 0.40 & 0.46 & 0.53 & 0.60 & 0.66 \\
IEAA & 35.4 & 14.8 & 17.7 & 20.4 & 23.4 & 26.3 & 29.2 \\
\hline
\end{tabular}

${ }^{a}$ according to Halver (1991)

$\mathrm{N} / \mathrm{A}=$ not available

Initially, all ingredients including oil were mixed with a food mixer for $20 \mathrm{~min}$, then tap water was added in order to prepare a suitable pulp, that was made into a $2 \mathrm{~mm}$ sized pellets with a meat grinder. The pelleted diets were then dried to a moisture content of $80-90 \mathrm{~g} / \mathrm{kg}$ at $40^{\circ} \mathrm{C}$ in a drying chamber. The test diets were then stored in a freezer $\left(-25^{\circ} \mathrm{C}\right)$ until use. Experimental fish were hand fed until satiation twice a day at 09:00 and 16:30 hours for a total of 90 days. Special attention was given to be certain of the even distribution of pellets by all fish in the tanks, and feeding lasted for about 15-20 min. When fish refused feeding, it was accepted as a sign of satiety and feeding was stopped in order to avoid overfeeding. In all tanks, the feed intake was recorded daily by subtracting the feed distributed from the initial weight of feed.

\subsection{Sampling and Analytical Methods}

Prior to the start of the experiment, 10 fish from the initial pool were anesthetized in a high dose MS-222 (100 mg/L) and stored in polyethylene bags in a freezer $\left(-25^{\circ} \mathrm{C}\right)$ for subsequent analysis. At the end of the experiment, the same protocol of sampling was followed for each tank. Five fish per tank (15 fish per treatment) were randomly withdrawn for comparative analysis of fish whole body (dry matter, protein, lipid, ash) and calculation of nutrient retention rates and nitrogen budget. All analyses were performed in triplicate and samples were prepared by homogenizing fish whole body in a kitchen blender. Chemical analyses of test diets and fish whole body were conducted according to [17] guidelines as follows: for dry matter, drying in an oven at $105^{\circ} \mathrm{C}$ for 24 $\mathrm{h}$ until constant weight were obtained; for protein $(\mathrm{Nx} 6.25)$ by Kjeldahl method after acid digestion; for lipids by ethylether extraction in a Soxhlet System; for ash by incineration in a muffle furnace at $550^{\circ} \mathrm{C}$ for $12 \mathrm{~h}$. The NFEs were calculated by substracting the sum of protein, lipid and ash from hundred.

\subsection{Statistical Analysis}

The results were given as mean \pm standard deviation (SD) and differences of group means were compared by one-way ANOVA. Significance level of $p<0.05$ was applied for all data. In order to figure out the optimum dietary protein level that matches with the maximum growth rate, a third order polynomial regression between dietary protein and growth rate values was applied [18].

\section{Results and Discussion}

At the end of the 90 days growth experiment, survival rates were over $85 \%$ for all treatment groups, indicating that dietary protein levels did not affect fish survival. Best growth performance in salema porgy juveniles were obtained when fed a diet with $37 \%$ protein. This was followed by the $30 \%$ and $40 \%$ diet groups, respectively. No significant difference ( $p>0.05$ ) was found between final body weight of fish fed the $37 \%$ protein diet and those fed diets with $30 \%$ or $40 \%$ protein levels. However, dietary protein levels over $40 \%$ significantly $(p<0.05)$ reduced the growth rates (Figure 1). The best specific growth rates (SGR) were obtained in fish fed the $37 \%$ protein diet, which demonstrated significantly better $(\mathrm{p}<0.05)$ performance compared to the higher protein diet. Eventhough there was no significant difference in SGRs between the $30 \%$ and $37 \%$ protein diets, the latter performed about $15 \%$ better than the $30 \%$ dietary protein group. A gradual decline was observed in percent feed intakes whith the decrease in dietary protein levels. The highest feeding rate of $0.69 \% \quad(p<0.05)$ was recorded in fish fed diets containing $37 \%$ protein. Based on the polynomial regression analyses [18] used for the relation between dietary protein levels and the SGRs, it was recorded that the optimum protein requirement for juvenile salema porgy was about $33.6 \%$ of the diet under the conditions applied in this study (Figure 2). The values for protein efficiency rates (PER) followed the same trend, with higher rates $(\mathrm{p}<0.05)$ for the best performing diet groups of $30 \%$ and $37 \%$, which demonstrated significantly lower $(\mathrm{p}<0.05)$ feed conversion rates (FCR) compared to the higher protein diets (Table 3 ).

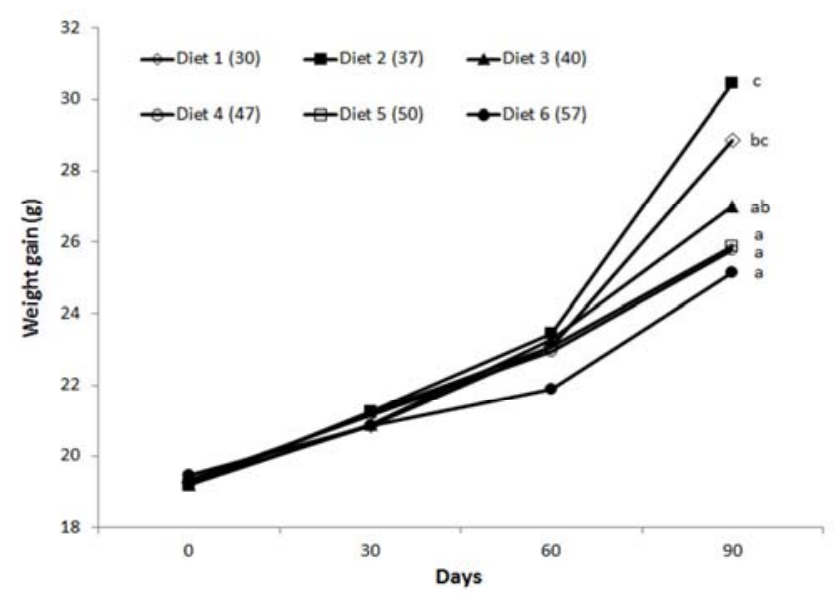

Figure 1. Growth of salema progy fed experimental diets. Values with different letters are significantly different $(p<0.05)$. 


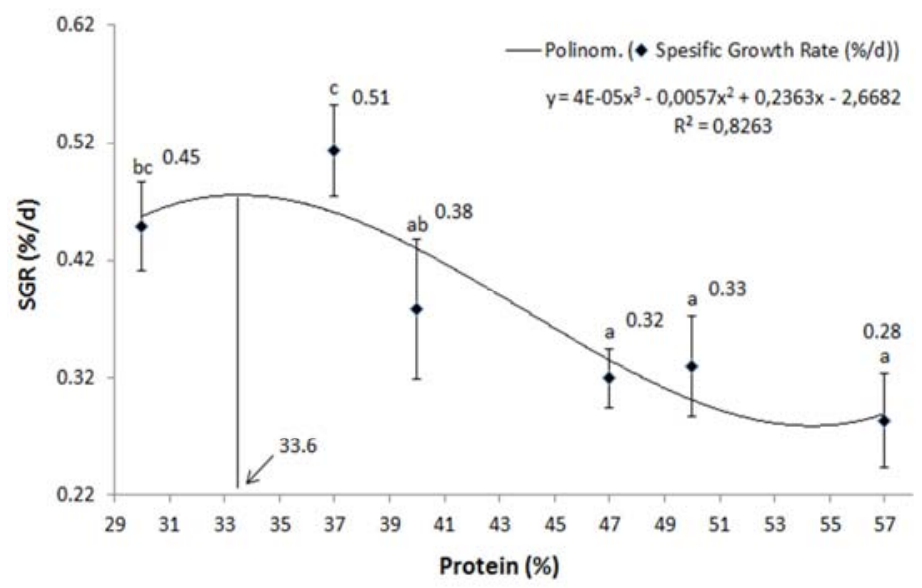

Figure 2. Optimum dietary protein requirement of salema porgy juvenile by polynomial regression between dietary protein levels and specific growth rates (SGR). Values with different letters are significantly different $(p<0.05)$.

Table 3. Growth and feed utilization of salema porgy fed the experimental diets for 90 days (means $\pm S D)^{*}$.

\begin{tabular}{|c|c|c|c|c|c|c|}
\hline \multicolumn{7}{|c|}{ Experimental diet / Protein level } \\
\hline D1/30 & D2/37 & D3/40 & D4/47 & D5/50 & D6/57 & \\
\hline IBW & $19.3 \pm 0.08$ & $19.2 \pm 0.04$ & $19.2 \pm 0.04$ & $19.3 \pm 0.10$ & $19.2 \pm 0.07$ & $19.5 \pm 0.14$ \\
\hline FBW & $28.9 \pm 1.03^{\mathrm{bc}}$ & $30.5 \pm 1.12^{\mathrm{c}}$ & $27.0 \pm 1.45^{\mathrm{ab}}$ & $25.8 \pm 0.44^{\mathrm{a}}$ & $25.9 \pm 1.09^{\mathrm{a}}$ & $25.2 \pm 1.04^{\mathrm{a}}$ \\
\hline SGR & $0.45 \pm 0.04^{\mathrm{bc}}$ & $0.51 \pm 0.04^{\mathrm{c}}$ & $0.38 \pm 0.06^{\mathrm{ab}}$ & $0.32 \pm 0.02^{\mathrm{a}}$ & $0.33 \pm 0.04^{\mathrm{a}}$ & $0.28 \pm 0.04^{\mathrm{a}}$ \\
\hline FI & $0.59 \pm 0.03^{\mathrm{b}}$ & $0.69 \pm 0.02^{\mathrm{c}}$ & $0.61 \pm 0.04^{\mathrm{b}}$ & $0.51 \pm 0.02^{\mathrm{a}}$ & $0.55 \pm 0.02^{\mathrm{ab}}$ & $0.52 \pm 0.03^{\mathrm{a}}$ \\
\hline FCR & $1.35 \pm 0.18^{\mathrm{ab}}$ & $1.24 \pm 0.12^{\mathrm{a}}$ & $1.66 \pm 0.35^{\mathrm{ab}}$ & $1.89 \pm 0.63^{\mathrm{ab}}$ & $1.71 \pm 0.26^{\mathrm{b}}$ & $1.88 \pm 0.37^{\mathrm{b}}$ \\
\hline PER & $2.56 \pm 0.33^{\mathrm{c}}$ & $2.22 \pm 0.23^{\mathrm{c}}$ & $1.50 \pm 0.32^{\mathrm{b}}$ & $1.22 \pm 0.35^{\mathrm{ab}}$ & $1.14 \pm 0.18^{\mathrm{ab}}$ & $0.96 \pm 0.19^{\mathrm{a}}$ \\
\hline SR & 87.18 & 92.31 & 89.74 & 84.62 & 84.62 & 87.18 \\
\hline
\end{tabular}

${ }^{*}$ Values with different superscript letters in the same line are significantly different at $\mathrm{p}<0.05$ level

IBW: initial body weight (g); FBW: final body weight (g)

SGR (specific growth rate, $\%$ growth per day) $=[(\ln W 2-\ln W 1) /(\mathrm{t} 2-\mathrm{t} 1)] \times 100$

FI $($ percent feed intake $\%$ per day $)=($ total feed intake $/((\mathrm{W} 1+\mathrm{W} 2) / 2) /$ day $) \times 100$

FCR $($ feed conversion rate $)=$ feed intake $(\mathrm{g}) /$ weight gain $(\mathrm{g})$

PER (protein efficiency rate) $=$ weight gain $(\mathrm{g}) /$ protein intake $(\mathrm{g})$

SR $($ survival rate,$\%)=($ number of remaining fish $/$ number of initial fish $) \times 100$

During the first 2 month of the trial, growth of salema porgy was relatively low, however after the 60 days of the feeding trial, the growth showed an increasing trend compared to the initial performance. Since the culture conditions were the same throughout the study, the acceleration of growth performance in the second month with an increasing trend in the third month of the trial might be attributed to the week adaptation of salema juveniles in tank environment. Eventhough the experimental fish were adapted for a period of 1 month to the culture conditions, and the feeding trial initiated when all fish accepted pellets, it seems that salema juveniles might need a longer acclimatization period to tank conditions of certain sizes. For instance, the best performing group in the present study showed a SGR of $0.5 \% /$ day throughout the feeding trial, while fish growth during the last period of 30-days resulted in an increased growth of $0.9 \%$ /day. The accelerated increase of growth performance after the 60-days of the feeding trial might be an indication for a better growth performance of salema when a longer adaptation period was applied.

The maximum SGR $(0.51 \% /$ day $)$ obtained for salema porgy in the present study was higher than an earlier report on axillary seabream (Pagellus acarne) $(0.23 \% /$ day) [19], another candidate sparid fish for aquaculture. Korkut and Balk1 [20] reported SGR variation of between 0.32 and $1.04 \% /$ day for gilthead seabream under commercial cage farm conditions in the Aegean Sea. Similar to the findings in the present study for salema porgy, Sá et al. [21] and Coutinho [22] also reported other sparid candidates such as white seabream (Diplodus sargus) $(0.89 \% /$ day) and zebra seabream (Diplodus cervinus) $(0.8 \% /$ day) as slow growing marine species, respectively. On the other hand, higher SGRs of $1.22 \%$ /day [23] and $1.54 \%$ /day [24] were recorded for two-banded seabream (Diplodus vulgaris) and sharpsnout seabream (Diplodus puntazzo), respectively.

Physico-chemical water parameters recorded in the present study were comparable and within the acceptable limits reported by [25] for a recirculating aquaculture system (Table 4). Water temperature during the course of the present study $\left(12.76 \pm 2.24^{\circ} \mathrm{C}\right)$ was relatively low compared to the data reported in the southern Aegean Sea where the average annual seawater temperature is in a range between $12.4-25^{\circ} \mathrm{C}$ [26]. Discrepancies between different reports might be due to rearing conditions such as water temperature, dissolved oxygen, salinity, fish stocking rates, feeding methods, or a 
combination of these factors [27, 28], as well as to fish species and fish size [29].

Table 4. Acceptable limits for different physico-chemical water quality parameters and recorded values in the present study.

\begin{tabular}{llll}
\hline Parameter & Unit & Acceptable limits $^{*}$ & Present study $^{*}$ \\
\hline $\mathrm{pH}$ & - & $6.5-7.5$ & $7.55 \pm 0.6$ \\
Temperature & ${ }^{\circ} \mathrm{C}$ & Species specific & $12.76 \pm 2.24$ \\
Salinity & $\mathrm{Ppm}$ & Species specific & $25.64 \pm 0.84$ \\
Oxygen & $\mathrm{O}_{2}, \%(\mathrm{mg} / \mathrm{L})$ & $70-100$ & $88(7.98 \pm 1.3)$ \\
Ammonium & $\mathrm{NH}_{3}, \mathrm{mg} / \mathrm{L}$ & $0-2.5(\mathrm{pH}$ influenced $)$ & $0.27 \pm 0.06$ \\
\hline
\end{tabular}

*Bregnballe, 2015

Dietary protein requirements estimated based on growth performance (percent growth per day) or nitrogen retention (per $\mathrm{N}$-intake) corresponded to $37 \%$ and $30 \%$, respectively. Similar to the findings in the present study, protein requirements for two-banded seabream (Diplodus vulgaris) were reported between $35-36 \%$ in earlier studies [23, 30], while a lower protein level of $27 \%$ was recorded for juvenile white seabream (Diplodus sargus) [21]. In contrast, higher protein levels for best growth were found for other sparids such as Blackfin seabream (Acanthopagrus berda) (42\%) [31], zebra seabream (D. cervinus) (43.8\%) [22], and sharsnout seabream (Diplodus puntazzo) (43-47\%) [24, 32]. Tacon and Cowey [33] reported that generally fast growing fish species require higher protein levels in their diets compared to the slow growing species. Apart from this, carnivorous fish species such as gilthead seabream ( $S$. aurata), European seabass (Dicentrarchus labrax), rainbow trout (Onchorhynchus mykiss), common dentex (Dentex dentex), Japanese flounder (Paralichthys olivaceus), or the red porgy (Pagrus pagrus) are reported to require higher levels of dietary protein (45-55\%) [34-39]. The lower protein requirement of salema porgy compared to other sparids or other marine fishes could be attributed to their herbivorous feeding nature, whereas the others requiring higher protein diets are either carnivorous or omnivorous species. This is in agreement with the statement of [40], indicating that carnivorous fishes have higher protein requirements compared to omnivorous or herbivorous species.

The regulation of feed intake in order to meet energy demand is general condition for fish [41]. This condition has also been reported for white seabream [21], in zebra seabream [22], in sharpsnout seabream [24, 42], and in Blackfin seabream [31]. The finding in the present study for the feed intake in salema porgy is in agreement with earlier reports, in terms of increased feed intake $(p<0.05)$ with the decrease of protein levels in the diets. In the present study, the FCRs of salema porgy linearly increased with the declining dietary protein levels. This is in agreement with the findings in white seabream [21], in sharpsnout seabream [24], and in Blackfin seabream [31]. In contrast, increased FCRs in zebra seabream [22] and gilthead seabream [43] were reported with increased dietary protein levels. The FCRs found in this study (1.24-1.89) were comparable with those reported earlier for two banded seabream (D. vulgaris) $(1.50-1.80,1.36-2.96,1.67-1.92)[30,44,45]$, in zebra seabream (1.69-3.33) [22], and in gilthead seabream (0.91$3.06,1.14-3.73,1.22-1.74,1.24-1.48,1.37-1.53)[20,27,28$, 43 , 46], respectively. Higher FCR of 2.51 was found in axillary seabream (Pagellus acarne), introduced as a new candidate species for the Mediterranean aquaculture by [19], while lower FCRs of 1.1-1.2 were reported in gilthead seabream [47]. Similar to the growth performance recorded in the present study, FCRs and PERs followed the same trend with better results in fish fed lower protein diets. These findings in the present study were in agreement with earlier reports on European eel Anguila anguila [48], Yellow snapper Lutjanus argentiventris [49], and two-banded Seabream D. vulgaris [30] in terms of decreasing PERs with increased dietary protein levels.

The nitrogen retention rates per intake in fish fed diets with $30 \%$ and $37 \%$ protein were significantly $(p<0.05)$ higher than those fed the higher protein diets. In contrast, excretion rate of nitrogen per intake were lowest for the fish fed on lower protein diets of 30 and $37 \%$ and showed a significant increase when dietary protein levels rose over $40 \%$ (Table 5).

Table 5. Nitrogen ( $N$ ) balance ( $\mathrm{mg} / \mathrm{g}$ production) of salema porgy fed experimental diets for 90 days (means $\pm S D)^{*}$

\begin{tabular}{|c|c|c|c|c|c|c|}
\hline \multicolumn{7}{|c|}{ Experimental diet / protein level } \\
\hline \multicolumn{7}{|l|}{$\mathbf{N}$ balance } \\
\hline D1/30 & D2/37 & D3/40 & D4/47 & D5/50 & D6/57 & \\
\hline NI & $73.5 \pm 18.4^{\mathrm{a}}$ & $83.4 \pm 12.1^{\mathrm{a}}$ & $110.2 \pm 23.5^{\mathrm{ab}}$ & $119.8 \pm 12.7^{\mathrm{b}}$ & $142.2 \pm 21.4^{\mathrm{bc}}$ & $171.6 \pm 33.6^{\mathrm{c}}$ \\
\hline NR & $30.1 \pm 2.54^{\mathrm{a}}$ & $30.3 \pm 1.83^{\mathrm{a}}$ & $31.2 \pm 5.81^{\mathrm{a}}$ & $31.1 \pm 2.47^{\mathrm{a}}$ & $27.9 \pm 2.97^{\mathrm{a}}$ & $30.0 \pm 5.16^{\mathrm{a}}$ \\
\hline TNE & $43.4 \pm 17.3^{\mathrm{a}}$ & $53.0 \pm 13.9^{\mathrm{ab}}$ & $79.0 \pm 17.7^{\mathrm{bc}}$ & $88.7 \pm 10.9^{c}$ & $114.3 \pm 18.4^{\mathrm{cd}}$ & $141.6 \pm 28.6^{\mathrm{d}}$ \\
\hline NR (\%NI) & $42.4 \pm 8.7^{\mathrm{d}}$ & $37.1 \pm 7.12^{\mathrm{d}}$ & $28.4 \pm 0.90^{\mathrm{c}}$ & $26.0 \pm 0.73^{\mathrm{c}}$ & $19.7 \pm 0.99^{\mathrm{b}}$ & $17.6 \pm 0.81^{\mathrm{a}}$ \\
\hline TNE $(\% \mathrm{NI})$ & $57.6 \pm 8.7^{\mathrm{a}}$ & $62.9 \pm 7.12^{\mathrm{a}}$ & $71.6 \pm 0.90^{\mathrm{b}}$ & $74.0 \pm 1.73^{\mathrm{b}}$ & $80.3 \pm 0.99^{c}$ & $82.5 \pm 0.81^{\mathrm{d}}$ \\
\hline
\end{tabular}

* Values with different superscript letters in the same line are significantly different at $\mathrm{p}<0.05$ level.

$\mathrm{NI}($ nitrogen intake, $\mathrm{mg} / \mathrm{g}$ production $)=($ protein intake $/ 6.25) /(\mathrm{W} 2-\mathrm{W} 1)$

$\mathrm{NR}$ (nitrogen retention, $\mathrm{mg} / \mathrm{g}$ production $)=($ total g protein retained in fish / 6.25) / (W2 - W1)

$\mathrm{TNE}$ (nitrogen total excretion, $\mathrm{mg} / \mathrm{g}$ production) $=($ nitrogen intake $(\mathrm{g})$-nitrogen retention $(\mathrm{g})) /(\mathrm{W} 2-\mathrm{W} 1)$

$\mathrm{NR}(\% \mathrm{NI}$, nitrogen retention as percent of nitrogen intake $)=100 \times(\mathrm{N}$ retention $/ \mathrm{N}$ intake $)$

TNE $(\%$ NI, nitrogen total excretion as percent of nitrogen intake $)=100 \times(\mathrm{N}$ excretion $/ \mathrm{N}$ intake $)$

W2: final fish weight $(\mathrm{g}), \mathrm{W} 1=$ initial fish weight $(\mathrm{g})$ 
The excessive supplement of dietary animal proteins may result in increased nitrogen excretion. The incorporation of dietary animal protein or lipids at an optimum level may support the aquaculture industry economically and environmentally [23]. In the present study, dietary protein levels over $40 \%$ resulted in a significant increase of nitrogen excretion, which can be explained by the elevated protein catabolism led to higher ammonia excretion rates in fish fed excessive dietary protein. This finding was also supported by the PERs in the present study with better protein utilization when fed diets lower than $40 \%$ protein. The findings in this study regarding nitrogen retention rates per intake (37-42\%) in best performing protein groups are in close agreement with earlier reports in European seabass fed different ration levels (36-43\%) [50], in rainbow trout (18-46\%) [51], Atlantic turbot (28-36\% and 36-42\%) [52, 53], the Black Sea turbot (38-40\%, 19-41\%, and 29-30\%) [54-56]. Lower retention rate of nitrogen per intake have been reported in Blackfin seabream $(20-40 \%)$ [31], zebra seabream $(19-26 \%)$ [22], European seabass $(23-32 \%$ and $16-26 \%)$ [57, 58]. Wilson [59] reported that the optimal protein level in fish diet might be affected by the amino acid composition of the test proteins. In earlier studies, it has been reported that feeding fish with diets over the requirement level may result in an increased protein catabolism [60], induced with the increase of hepatic activity of alanine aminotransferase, aspartate aminotransferase, and glutamate dehydrogenase enzyme activities [61-63]. In the present study, eventhough enzyme activities were not investigated, the reason for the higher nitrogen excretion rates in experimental fish fed higher levels of dietary protein might be attributed to the increased protein catabolism due to the excessive protein levels in the diets.

As a new candidate species for the aquaculture sector, there is no data available on the essential amino acid (EAA) requirements of salema porgy. Considering the best performing diet of $37 \%$, and the reduction in fish growth when fed in excess of requirements, might also be linked to an excessive dietary EAAs for the test diets containing protein levels over $40 \%$. Hence, based on the findings in the present study, it might be assumed that the amino acid profile of the best performing diet (37\%) is close to ideal EAA profile for salema porgy juveniles. Because, at this level of dietary protein, there were no limitation of amino acids in the test diets, that otherwise could have resulted in growth limitations of fish. Actually, fish diets below ideal protein profile lacking in one or more EAA can lead to reduced feed intake and growth performance, depress protein or amino acid retention, due to higher protein and amino acid catabolism, which in turn lead to increased nitrogen waste and deterioration of environment waters $[22,31,51,57,60,64]$.

A slight decrease in fish whole body protein was observed when dietary protein levels increased over $40 \%$ level, however no significance $(\mathrm{p}>0.05)$ was recorded among the experimental groups. Crude lipid contents of fish body followed the same trend with no significant differences $(p>0.05)$ among test groups. Fish body ash contents tended to increase with increasing levels of dietary protein, however these differences were not significantly $(\mathrm{p}>0.05)$ important as well (Table 6). The hepatosomatic index (HSI) in salema porgy juveniles fed diets with 47,50 , and $57 \%$ protein were higher than those of the 30,37 , and $40 \%$ dietary protein groups. However, the increasing trend of the HSIs observed here was not significantly $(\mathrm{p}>0.05)$ important (Table 7).

Table 6. Whole body proximate composition (dry basis, except for moisture) of salema porgy fed experimental diets for 90 days (means $\pm S D)^{*}$.

\begin{tabular}{lllll}
\hline Diets & $\begin{array}{l}\text { Moisture } \\
(\%)\end{array}$ & $\begin{array}{l}\text { Crude } \\
\text { Protein (\%) }\end{array}$ & $\begin{array}{l}\text { Crude lipid } \\
(\%)\end{array}$ & $\begin{array}{l}\text { Crude ash } \\
(\%)\end{array}$ \\
\hline Initial & $75.2 \pm 0.28$ & $72.2 \pm 0.95^{\mathrm{a}}$ & $13.4 \pm 1.17$ & $12.2 \pm 0.51$ \\
D1/30 & $75.8 \pm 0.32$ & $75.1 \pm 0.77^{\mathrm{b}}$ & $12.1 \pm 0.59$ & $12.1 \pm 0.23$ \\
D2/37 & $75.7 \pm 0.40$ & $75.3 \pm 0.84^{\mathrm{b}}$ & $12.0 \pm 0.40$ & $11.9 \pm 0.30$ \\
D3/40 & $75.5 \pm 0.45$ & $74.9 \pm 0.80^{\mathrm{b}}$ & $12.1 \pm 0.68$ & $12.2 \pm 0.46$ \\
D4/47 & $75.6 \pm 0.43$ & $74.6 \pm 0.27^{\mathrm{b}}$ & $12.0 \pm 0.59$ & $12.3 \pm 0.53$ \\
D5/50 & $76.1 \pm 0.63$ & $74.6 \pm 0.48^{\mathrm{b}}$ & $11.5 \pm 1.15$ & $12.8 \pm 0.69$ \\
D6/57 & $75.9 \pm 0.49$ & $74.3 \pm 0.50^{\mathrm{b}}$ & $11.9 \pm 1.17$ & $12.8 \pm 0.81$ \\
\hline
\end{tabular}

* Values with different superscript letters in the same row are significantly different at $\mathrm{p}<0.05$ level.

Table 7. Body morphological indices of salema porgy juveniles fed experimental diets for 90 days (means $\pm S D$ )*.

\begin{tabular}{lll}
\hline Diets & HIS & VSI \\
\hline Initial & $1.68 \pm 0.66$ & $6.91 \pm 1.14$ \\
D1/30 & $1.52 \pm 0.27$ & $6.11 \pm 0.52$ \\
D2/37 & $1.51 \pm 0.50$ & $6.36 \pm 0.87$ \\
D3/40 & $1.53 \pm 0.21$ & $6.37 \pm 0.41$ \\
D4/47 & $1.60 \pm 0.64$ & $6.71 \pm 0.92$ \\
D5/50 & $1.83 \pm 0.39$ & $7.27 \pm 0.67$ \\
D6/57 & $1.66 \pm 0.16$ & $6.49 \pm 0.13$ \\
\hline
\end{tabular}

* Values with no superscript letters in the same row are not significantly different at $\mathrm{p}<0.05$ level

HSI, hepatosomatic index $=($ liver weight $/$ total weight $) \times 100$

VSI, viscerasomatic index $=($ viscera weight $/$ total weight $) \times 100$

The liver is known to have a function as the deposition site for fat and glycogen in fish [65, 66]. Dietary carbohydrates were reported to stimulate glycolysis, glycogenesis and lipogenesis, while reducing protein catabolism and gluconeogenesis [67]. In the present study, protein levels and NFEs (soluble carbohydrate of the feed) of the test diets were negatively correlated, with increasing carbohydrates at decreasing levels of dietary protein. Due, the increased carbohydrate levels in the present test diets with lower dietary protein might have stimulated the lower protein catabolism. It has been reported that HSI is positively correlated with dietary carbohydrate levels, while inversely related to dietary protein $[22,24,68,69]$. In the present study however, an adverse relation between HSI and carbohydrate level, but positive correlation with dietary protein levels were observed. The VSI showed similar trend as the HSI in the present study.

Considering that the best growth was obtained with the low protein diets $(30-40 \%)$, which were higher in NFEs (23$38 \%$ vs $2-15 \%$ ) but lower in protein to energy (P:E) ratio $(15-20 \mathrm{mg} / \mathrm{kJ}$ vs $22-27 \mathrm{mg} / \mathrm{kJ})$, compared to the higher protein diets (47-57\%) might be attributed to the herbivorous 
nature of salema porgy and also linked to a hypothesis that salema porgy might prefere low-protein but high-energy diets for a best growth performance, as also reported in twobanded seabream [30]. However, the experimental diets in the present study were formulated with a single lipid level. Further studies are encouraged to assess dietary lipid and carbohydrate levels for salema porgy with experimentations at different water temperature regimes.

\section{Conclusion}

In the present study, optimum dietary protein requirement of salema porgy juveniles by polynomial regression between protein levels and growth rates was found as $33.6 \%$, indicating that this low level of dietary protein is optimum for maximum growth and feed conversion ratio in salema porgy juveniles. Increasing the dietary protein over $40 \%$ seems to induce a decline on weight gain, and negatively affect the protein efficiency as well as nitrogen retention rates. As a marine fish species with low protein requirements, salema porgy might be a promising candidate for the Mediterranean aquaculture industry, with the less use of fishmeal based protein sources, that in long run might benefit the global aquaculture in terms of economically sustainable and environment friendly way.

\section{Acknowledgement}

Canakkale Onsekiz Mart University, Scientific Research Projects Commission (COMU-BAP) is acknowledged for the support of laboratory equipments used in this study with the Project ID: 256 and Project Code: FAY-2014-256. COMU, Faculty of Marine Science and Technology is acknowledged for the use of experimental facilities throughout the study, which has been performed in partial fulfillment of requirements for the degree of Master of Science of the first author.

\section{References}

[1] FAO, Fisheries and Aquaculture Information and Statistics Branch, Food and Agriculture Organization of the United Nations, Global Production Statistics, $\mathrm{http} / / / w w w . f a o . o r g /$ fishery/statistics/global-production/en, 2016.

[2] United Nations, Probabilistic population projections based on the World population prospects: The 2015 Revision. United Nations, Population Division, DESA, http://esa.un.org/unpd/ppp/, 2015.

[3] A. Criscoli, F. Colloca, P. Carpentieri, A. Belluscio, and G. Ardizzone, "Observation on the reproductive cycle, age and growth of the salema, Sarpa salpa (Osteichthyes: Sparidae) along the western central coast of Italy," Sci. Mar., vol. 70, pp. 131-138, 2006.

[4] L. Steele, K. M. Darnell, J. Cebrián, and J. L. Sanchez-Lizaso, "Sarpa salpa Herbivory on shallow reaches of Posidonia oceanica beds," Anim. Biodivers. Conserv., vol. 37(1), pp. 49-

\section{$57,2014$.}

[5] J. L. B. Smith, and M. M. Smith, "Sparidae," in Sea Fishes, M. M. Smith and P. C. Heemstra, Eds. Smiths' Berlin: Springer-Verlag, 1986, pp. 580-594.

[6] M. L. Bauchot, and J. C. Hureau, "Sparidae," in Checklist of the fishes of the Eastern Tropical Atlantic Catalogue des poissons de l'Atlantique tropical oriental (Clofeta), vol. III, J. C. Quéro, J. C. Hureau, C. Karrer, A. Post, L. Saldanh, Eds. Paris: Unesco, 1990, pp. 790-812.

[7] A. Colorni, and A. Diamant, "Infectious diseases of warmwater fish in marine and brackish waters," in Diseases and Disorders of Finfish in Cage Culture, 2nd ed., P. T. K. Woo, and D. W. Bruno, Eds. Wallingford UK: CABI Publishing, 2014, pp. 155-192.

[8] S. Msangi, M. Kobayashi, M. Batka, S. Vannuccini, M. M. Dey, and J. L. Anderson, Fish to 2030. Prospects for Fisheries and Aquaculture. Washington, USA: The World Bank Publication, report no. 83177-GLB, 2013.

[9] I. Nengas, M. N. Alexis, and S. J. Davies, "Partial substitution of fishmeal with soybean meal products and derivatives in diets for gilthead seabream Sparus aurata (L.)," Aquac. Res., vol. 27 , pp. 147-156, 1996.

[10] A. G. J. Tacon, and M. Metian, "Global overview on the use of fish meal and fish oil in industrially compounded aquafeeds: Trends and future prospects," Aquaculture, vol. 285, pp. 146-158, 2008.

[11] M. Yigit, S. Ergün, A. Türker, B. Harmantepe, and A. Erteken, "Evaluation of soybean meal as a protein source and its effect on growth and nitrogen utilization of black sea turbot ( $p$ setta maeotica) juveniles. J. Mar. Sci. Technol.-TA, vol. 18(5), pp. 682-688, 2010.

[12] N. Neofitou, "Waste feed from fish farms of the Eastern Mediterranean and attraction of wild fish," Universal J. Geosci., vol. 4(5), pp. 112-115, 2016.

[13] M. M. Villamil, J. M. Lorenzo, J. G. Pajelo, A. Ramos, and J. Coca, "Aspects of the history of salema, Sarpa salpa (Pisces, Sparidae), off the Canarian Arcipelago (central-east Atlantic)," Environ. Biol. Fish., vol. 63, pp. 183-192, 2002.

[14] S. Matić-Skoko, M. Kraljević, J. Dulčić, and A. Pallaoro, "Growth of juvenile salema, Sarpa salpa (Teleostei: Sparidae), in the Kornati Archipelago, eastern Adriatic Sea," Sci. Mar., vol. 68(3), pp. 411-417, 2004.

[15] T. Dobroslavić, A. Zlatovié, V. Bartulović, D. Lučić, and B. Glamuzina, "Diet overlap of juvenile salema (Sarpa salpa), bogue (Boops boops) and common two-banded sea bream (Diplodus vulgaris) in the south-eastern Adriatic," J. Appl. Ichthyol., vol. 29, pp. 181-185, 2013.

[16] B. Bayhan, and A. Kara, "Length-weight and length-length relationships of the salema Sarpa salpa (Linnaeus, 1758) in Izmir Bay (Aegean Sea of Turkey)," Pak. J. Zool., vol. 47(4), pp. 1141-1146, 2015.

[17] AOAC, Association of Official Analytical Chemists. Maryland, USA: Official Methods of Analysis of AOAC International, 1998.

[18] J. R. Brett, and T. D. D. Grove, "Physiological energetics in fish", in Fish Physiology, W. S. Hoar, D. J. Randall, and J. R. Brett, Eds. New York: Academic Press, 1979, pp. 279-352. 
[19] M. Yigit, B. Celikkol, M. Bulut, J. Decew, H. B. Ozalp, S. Yilmaz, H. Kaya, B. Kizilkaya, O. Hisar, H. Yildiz, Ü. Yigit, M. Sahinyilmaz, R. L., Dwyer, "Monitoring of trace metals, biochemical composition and growth of Axillary seabream (Pagellus acarne Risso, 1827) in offshore copper alloy mesh cages," Mediterr. Mar. Sci., vol. 17(2), pp. 396-403, 2016.

[20] A. Y. Korkut, and D. Balk1, "Effects of different feeding rations on growth of gilthead seabream (Sparus aurata L., 1758) in net cages," Ege J. Fish. Aquat. Sci., vol. 21, pp. 235238, 2004.

[21] R. Sá, P. Pousao-Ferreira, and A. Olive-Teles, "Dietary protein requirement of White sea bream (Diplodus sargus) juveniles. Aquacult. Nutr., vol. 14, pp. 309-317, 2008.

[22] F. F. Coutinho, "Dietary protein requirement and intermediary metabolism response to protein/carbohydrate ratio in zebra seabream (Diplodus cervinus, Lowe 1838) juveniles," Master of Science Thesis. Porto Portugal: Faculty of Science, University of Porto, 2012.

[23] R. O. A. Ozório, L. M. P. Valente, S. Correia, P. PousaoFerreira, A. Damasceno-Oliveira, C. Escorcio, and A. OliviaTeles, "Protein requirement for maintenance and maximum growth of two-banded seabream (Diplodus vulgaris) juveniles. Aquacult. Nutr., 15, 85-93.

[24] Coutinho, F., Peres, H., Guerreiro, I., Pousão-Ferreira, P., \& OlivaTeles, A. (2012). Dietary protein requirement of sharpsnout sea bream (Diplodus puntazzo, Cetti 1777) juveniles. Aquaculture, 356, 391-397.

[25] J. Bregnballe, "A guide to recirculation aquaculture, an introduction to the new environmentally friendly and highly productive closed fish farming systems," Publication of Food and Agriculture Organization of the United Nations (FAO) and EUROFISH International Organisation, http://www.fao.org/3/a-i4626e.pdf, 2015.

[26] B. Hossu, A. Y. Korkut, and S. Salnur, "Investigation on feeding tables for seabass (Dicentrarchus labrax L., 1758) in net-cage (Pinar Marine Company) culture. Mediterranean Fish Nutrition, in Cahiers Options Méditerranéennnes, vol. 63, D. Montero, B. Basurco, I. Nengas, M. Alexis and M. Izquierdo, Eds. Zaragoza: CIHEAM Centre International de Hautes Etudes Agronomiques Méditerranéennes/HCMR Hellenic National Centre for Marine Research, 2005, pp. 158.

[27] M. M. Taher, "Effect of fish density and feeding rates on growth and food conversion of gilthead seabream (Sparus aurata Linnaeus, 1758). Iraq Aquacult. J., vol. 1, pp. 25-35, 2007.

[28] M. Yigit, M. Bulut, S. Ergün, D. Güroy, M. Karga, O. S., Kesbiç, S. Yılmaz, Ü. Acar, and B. Güroy, "Utilization of corn gluten meal as a protein source in diets for gilthead sea bream (Sparus aurata L.) juveniles. J. FisheriesSciences.com, vol. 6(1), pp. 63-73, 2012.

[29] I. Lupatsch, G. W. M. Kissil, D. Sklan, and E. Pfeffer, "Effects of varying dietary protein and energy supply on growth, body composition and protein utilization in gilthead sea bream (Sparus aurata L.). Aquacult. Nutr., vol. 7, pp. 71-80, 2001.

[30] M. Bulut, M. Yigit, S. Ergün, O. S. Kesbic, Ü. Acar, N. Gültepe, M. Karga, S. Yılmaz, and D. Güroy, "Evaluation of dietary protein and lipid requirements of two-banded seabream (Diplodus vulgaris) cultured in a recirculating aquaculture system. Aquacult. Int., vol. 22, pp. 965-973, 2014a.
[31] A. Rahim, G. Abbas, S. Ferrando, L. Gallus, A. Ghaffar, A. Mateen, M. Hafeez-ur-Rehman, and B. Waryani, "Effects of varying dietary protein level on growth, nutrient utilization and body composition of juvenile Blackfin sea bream, Acanthopagrus berda (Forsskal, 1775). Pak. J. Zool., vol. 48(4), pp. 1089-1097, 2016.

[32] M. T. Atienza, S. Chatzifotis, and P. Divanach, "Macronutrient selection by sharp snout sea bream (Diplodus puntazzo). Aquaculture, vol. 232, pp. 481-491, 2004.

[33] A. G. J. Tacon, and C. B. Cowey, "Protein and amino acid requirements," in Fish Energetics, P. Tytler, P. Calow and C. Helm, Eds. London \& Sydney: New Perspectives, 1985, pp. 155-183.

[34] J. J. Sabaut, and P. Luquet, "Nutritional requirements of the gilthead bream Chrysophrys aurata. Quantitative protein requirements,” Mar. Biol., vol. 18, pp. 50-54, 1973.

[35] F. Hidalgo, and E. Alliot, "Influence of water temperature on protein requirement and protein utilization in juvenile sea bass, Dicentrarchus labrax," Aquaculture, vol. 72, pp. 115129, 1988.

[36] K. Kim, B. T. Kayes, and H. C. Amundson, "Purified diet development and re-evaluation of the dietary protein requirement of fingerling rainbow trout (Oncorhynchus mykiss)," Aquaculture, vol. 96, pp. 57-67, 1991.

[37] F. J. Espinos, A. Tomás, L. M. Pérez, J. Balasch, and M. Jover, "Growth of dentex fingerlings (Dentex dentex) fed diets containing different levels of protein and lipid," Aquaculture, vol. 218, pp. 479-490, 2003.

[38] M. Yigit, S. Koshio, S. Teshima, and M. Ishikawa, "Dietary protein and energy requirements of juvenile Japanese flounder, Paralichthys olivaceus," J. Appl Sci., vol. 4(3), pp. 486-492, 2004.

[39] D. Schuchardt, J. M. Vergara, H. Fernández-Palacios, C. T. Kalinowski, C. M. Hernández-Cruz, M. S. Izquierdo, L. Robaina, "Effects of different dietary protein and lipid levels on growth, feed utilization and body composition of the red porgy (Pagrus pagrus) fingerlings," Aquacult. Nutr., vol. 14, pp. 1-9, 2008.

[40] NRC, Nutrient requirements of fsh and shrimp. National Research Council. Washington, USA: National Academies, 2011.

[41] S. J. Kaushik, and F. Medale, "Energy requirements, utilization and dietary supply to salmonids," Aquaculture, vol. 124, pp. 81-97, 1994.

[42] M. Vivas, V. C. Rubio, F. J. Sánchez-Vázquez, C. Mena, B. G. García, J. A. Madrid, "Dietary self-selection in sharpsnout seabream (Diplodus puntazzo) fed paired macronutrient feeds and challenged with protein dilution," Aquaculture, vol. 251, pp. 430-437, 2006.

[43] K. S. Ekmann, J. Dalsgaard, J. Holm, P. J. Campbell, P. V. Skov, "Effects of dietary energy density and digestible protein:energy ratio on de novo lipid synthesis from dietary protein in gilthead sea bream (Sparus aurata) quantified with stable isotopes," Brit. J. Nutr., vol. 110, pp. 1771-1781, 2013.

[44] M. Bulut, M. Yiğit, S. Ergün, O. S. Kesbiç, Ü. Acar, M. Karga, D. Güroy, "Incorporation of corn gluten meal as a replacement for fish meal in the diets of two banded seabream (Diplodus vulgaris) juveniles,” Int. J. AgriSci., vol. 4, pp. 60-65, 2014 b. 
[45] O. S. Kesbic, Ü. Acar, M. Yigit, M. Bulut, N. Gültepe, and S. Yilmaz, "Unrefined peanut oil as a lipid source in diets for juveniles of twobanded seabream Diplodus vulgaris," N. Am. J. Aquacult., vol. 78(1), pp. 64-71, 2016.

[46] F. Mongile, A. Bonaldo, R. Fontanillas, L. Mariani, A. Badiani, E. Bonvini, and L. Parma, "Effects of dietary lipid level on growth and feed utilisation of gilthead seabream (Sparus aurata L.) reared at Mediterranean summer temperature,” Ital. J. Anim. Sci., vol. 13, pp. 30-34, 2014.

[47] A. A. Bischoff, N. Kube, B. Wecker, and U. Waller, "MAREMarine artificial recirculated ecosystem: Steps towards closed systems for the production of marine organisms," in Lessons from the Past to Optimise the Future, vol. 35, B. Howell, and R. Flos, Eds. Oostende Belgium: ESA special publication, 2005, pp. 135-136.

[48] M. De La Higuera, M. García Gallego, A. Sanz, M. C. Hidalgo, and M. D. Suárez, "Utilization of dietary protein by the eel (Anguilla anguilla): optimum dietary protein levels," Aquaculture, vol. 79, pp. 53-61, 1989.

[49] M. Maldonado-García, J. Rodríguez-Romero, M. ReyesBecerril, C. A. Álvarez-González, R. Civera-Cerecedo, and M. Spanopoulos, "Effect of varying dietary protein levels on growth, feeding efficiency, and proximate composition of yellow snapper Lutjanus argentiventris (Peters, 1869)," Lat. Am. J. Aquat. Res., vol. 40(4), pp. 1017-1025, 2012.

[50] H. Peres, and A. Oliva-Teles, "Protein and energy metabolism of European seabass (Dicentrarchus labrax) juveniles and estimation of maintenance requirements," Fish Physiol. Biochem., vol. 31, pp. 23-31, 2005.

[51] J. A. Green, R. W. Hardy, and E. L. Brannon, "The optimum dietary essential:nonessential amino acid ratio for rainbow trout (Oncorhynchus mykiss), which maximizes nitrogen retention and minimizes nitrogen excretion," Fish Physiol. Biochem., vol. 27, pp. 109-115, 2002.

[52] C. Burel, T. Boujard, S. J. Kaushik, G. Boeuf, S. Van Der Geyten, K. A. Mol, E. R. Kühn, A. Quinsac, M. Krouti, and D. Ribaillier, "Potential of plant-protein sources as fish meal substitutes in diets for turbot (Psetta maxima): growth, nutrient utilization and thyroid status," Aquaculture, vol. 188, pp. 363-382, 2000.

[53] V. Fournier, C. Huelvan, and E. Desbruyeres, "Incorporation of a mixture of plant feedstuffs as substitute for fish meal in diets of juvenile turbot (Psetta maxima)," Aquaculture, vol. 236, pp. 451-465, 2004.

[54] A. Turker, M. Yigit, S. Ergun, B. Karaali, and A. Erteken, "Potential of poultry by-product meal as a substitute for fishmeal in diets for Black Sea turbot Scophthalmus maeoticus: Growth and Nutrient Utilization in Winter. Isr. J. Aquacult.-Bamid., vol. 57(1), pp. 49-61, 2005.

[55] M. Yigit, M. Erdem, S. Koshio, S. Ergün, A. Türker, and B. Karaali, "Substituting fish meal with poultry by-product meal in diets for Black Sea turbot Psetta maeotica, Aquacult. Nutr., vol. 12, pp. 340-347, 2006.

[56] F. B. Harmantepe, M. Yigit, G. Dogan, Z. Karsli, U. Yigit, and O. Uyan, "Effects of dietary lipid levels on growth performance and feed utilization in juvenile Black Sea turbot
(Psetta maxima) with reference to nitrogen excretion," Mar. Sci. Technol. Bull., vol. 3(2), pp. 21-26, 2014.

[57] F. Tulli, C. Vachot, E. Tibaldi, V. Fournier, and S. J. Kaushik, "Contribution of dietary arginine to nitrogen utilisation and excretion in juvenile sea bass (Dicentrarchus labrax) fed diets differing in protein source," Comp. Biochem. Phys. A, vol. 147(1), 179-188. 2007.

[58] F. Tulli, M. Messina, M. Calligaris, and E. Tibaldi, "Response of European sea bass (Dicentrarchus labrax) to graded levels of methionine (total sulfur amino acids) in soya protein-based semi-purified diets," Brit. J. Nutr., vol. 104, pp. 664-673, 2010.

[59] R. Wilson, "Amino acids and proteins," in Fish Nutrition, J. E. Halver, Ed. San Diego: Academic Press, 1989, pp. 112-153.

[60] R. P. Wilson, "Amino acids and proteins," in: Fish Nutrition, 3rd ed, J. E. Halver, and R. W. Hardy, Eds. New York: Academic Press, 2002, pp. 143-179.

[61] D. A. J. Stone, "Dietary carbohydrate utilization by fish," Rev. Fish. Sci., vol. 11, pp. 337-369, 2003.

[62] J. F. Bibiano, L. M. Lundstedt, I. Meton, I. V. Baanante, and G. Moraes, "Effects of dietary levels of protein on nitrogenous metabolism of Rhamdia quelen (Teleostei: Pimelodidae)," Comp. Biochem. Phys. A., vol. 145, pp. 181-187, 2006.

[63] J. Gaye-Siessegger, U. Focken, and K. Becker, "Effect of dietary protein/carbohydrate ratio on activities of hepatic enzymes involved in the amino acid metabolism of Nile tilapia, Oreochromis niloticus (L.)," Fish Physiol. Biochem., vol. 32, pp. 275-282, 2006.

[64] M. Yigit, Ö. Yardim, and S. Koshio, "The protein sparing effects of high lipid levels in diets for rainbow trout (Oncorhynchus mykiss, W. 1792) with special reference to reduction of total nitrogen excretion. Isr. J. Aquacult.-Bamid., vol. 54(2), pp. 79-88, 2002.

[65] G. McClelland, G. Zwingelstein, J. M. Weber, and G. Brichon, "Lipid composition of tissue and plasma in two Mediterranean fshes, the gilthead seabream (Chrysophyrys auratus) and the European seabass (Dicentrarchus labrax)," Can. J. Fish. Aquat. Sci., vol. 52, pp. 161-170, 1995.

[66] H. Péres, P. Gonçalves, and A. Oliva-Teles, "Glucose tolerance in gilthead seabream (Sparus aurata) and European seabass (Dicentrarchus labrax)," Aquaculture, vol. 179, pp. 415-423, 1999.

[67] A. Pérez-Jiménez, M. C. Hidalgo, A. E. Morales, M. Arizcun, E. Abellan, and G. Cardenete, "Use of different combinations of macronutrients in diets for dentex (Dentex dentex) Effects on intermediary metabolism," Comp. Biochem. Phys. A, vol. 152, pp. 314-321.

[68] F. Wang, H. Han, Y. Wang, and X. Ma, "Growth, feed utilization and body composition of juvenile golden pompano Trachinotus ovatus fed at different dietary protein and lipid levels," Aquacult. Nutr., vol. 19, pp. 360-367, 2013.

[69] W. Li, X. Wen, J. Zhao, S. Li, and D. Zhu, "Effects of dietary protein levels on growth, feed utilization, body composition and ammonia-nitrogen excretion in juvenile Nibea diacanthus," Fisheries Sci., vol. 82, pp. 137-146, 2016. 